\title{
Development of Ubiquitous Learning Environment Based on Moodle Learning Management System
}

\author{
https://doi.org/10.3991/ijim.v14i14.11775 \\ I Kadek Suartama ${ }^{(凶)}$ \\ Universitas Pendidikan Ganesha, Singaraja, Indonesia \\ ik-suartama@undiksha.ac.id \\ Punaji Setyosari, Sulthoni, Saida Ulfa \\ Universitas Negeri Malang, Malang, Indonesia
}

\begin{abstract}
The digitalization of society, changes in the structure of education, and increasingly rapid resources have accelerated the development of an open learning environment. The application of electronic learning and mobile learning raises several new problems such as alienating students from the real world, the difficulty of students focusing on learning goals, giving students opportunities to spend their learning time with entertainment, to the problem of increasing the cognitive load of students. Ubiquitous learning, as a continuation of the evolution of electronic learning and mobile learning, offers more than just the latest educational ideas or methods, where this system can accommodate students and their learning styles by providing adequate information anytime and anywhere based on their characteristics, needs, and desire to improve academic performance and productivity. The purpose of this study is to 1) develop the ubiquitous learning environment including the ubiquitous learning portal built with the Moodle LMS, and the ubiquitous learning course in the Instructional Media course 2) find out the feasibility of the ubiquitous learning environment that has been developed. This study used the R\&D for Education model implementing some stages including analysis, design, development, and evaluation. All stages have been completed to make a portal and ubiquitous learning course in the Instructional Media course that meet the eligibility criteria as a source/instructional media and has feasibility to use in learning.
\end{abstract}

Keywords - Ubiquitous learning, Moodle, learning management system, instructional media.

\section{Introduction}

Recently, the concept of learning can be approached using constructivism paradigm. Constructivism understanding of learning states that learning is the result of its own construction (students) as a result of its interaction with the learning environment [1]. Based on the paradigm of constructivism about learning, the principle of media mediated instruction occupies a strategic position in order to 
realize learning events optimally. The variety of activities and the use of media/resources in learning continue to grow and develop along with the development of information and communication technology. Information and communication technology enables the emergence of various activities that can transform conventional services into flexible, personal, and effective activities by utilizing technological devices and digital resources [2], [3]. The real consequence of the rapid development of information and communication technology is the emergence of the concept of learning that can be done anywhere and anytime. In the past, information technology products such as mobile phones, electronic devices (gadgets), cloud computing, wireless networks, etc. had become the main promoters and accelerators of the application of the concept of mobile learning [4].

Previous research shows that mobile learning can increase student participation and achievement and help them learn. Instead of only learning in a formal learning environment, students can learn throughout their lives, using very different tools and technologies [5]-[8]. Even though mobile learning has a big influence in encouraging learning, it's considered not perfect. There can be found a lot of problems that need to be solved. Several studies have found problems that arise from the application of online learning/mobile learning. Odukoya, Adekeye, \& Okunlola [9] state that a mobile device is like a double-edged sword in terms of it can provide opportunities for positive learning experiences while promoting negative activities. Inaccurate learning strategies used in mobile learning make students busy downloading videos, films and music while others spend hours playing games or chatting on social networks; in this case, this reduces performance and academic productivity. Without the right motivation, students' opportunities to learn using online learning platform will be in vain [10]. E-learning can alienate students from the world or real life [11]. Mobile learning can also have other negative effects, especially overload on the students' cognitive load if the learning strategies used are inappropriate [12]. These findings offer a good reference for those of us who intend to design and carry out online/mobile learning activities better.

Pedagogical factors have the greatest influence on the success and intention and behavior of students to adopt mobile learning including the provision of richer content/teaching materials, strategies, and learning environments that can improve student learning performance [13]. One of the principles of selecting and using teaching materials/media, strategies and effective learning environments is to pay attention to individual differences in students. Students will learn in different ways and speeds based on their needs, interests or desires. Implementing methods based on the needs, interests, and characteristics of students will create a conducive learning atmosphere and improve student achievement [14]. One of the innovative learning strategies which is in accordance with the principles of learning is ubiquitous learning. The purpose of ubiquitous learning is to accommodate students and their learning styles by providing adequate information anytime and anywhere based on their needs and desires [15]. Ubiquitous learning integrates authentic learning spaces, ubiquitous digital resources, functional objects, mobile devices, and wireless networks and enables learning on demand, based on students' personal needs and their own activities [16]. 
Ubiquitous learning offers more than the latest educational ideas or methods. This term carries a vision of learning that is connected at all stages where we play out our lives. Learning takes place not only in the classroom, but also at home, work, playgrounds, libraries, museums and nature, and in our daily interactions with others. In addition, learning becomes part of doing; we do not learn to live more complete, but rather we learn to live fully. Learning is through active involvement, and significantly, it is no longer identified by reading texts or listening to lectures, but occurs through all the senses of sight, hearing, touch, and feeling [17]. In essence, the application of ubiquitous learning is a sign of the transformation of education in universities that apply it [18]. Because it is supported by information and communication technology, students can easily move from one place to another, across space and time, without having to worry about disruption in the learning process activities. In short, ubiquitous learning works on three main resources, namely: learning collaborators, learning contents, and learning services [19]-[21].

The ubiquitous learning systems can be developed using online learning systems [22]. The online learning system will support the characteristics of ubiquitous learning. Lau [23] states that the effective ubiquitous learning environment can be created using various components of information and communication technology to support students in the learning process, namely: 1) flexibility in digital platforms, 2) stimulation in a digital environment, 3) flexible discussion platforms, 4) student's confidence in digital communication, and 5) learning motivation and creativity.

The ubiquitous learning system can be developed using Moodle platform; in which Moodle stands for "Modular Object-Oriented Dynamic Learning Environment." Moodle has become a term that is synonymous with software packages designed to help educators create quality online learning; in this case, Moodle is a Learning Management System/LMS [24]. This is an open source software package designed using pedagogical principles, to help educators create effective online learning communities. These pedagogical principles are the basis of social constructionism that makes Moodle a platform that is specifically suitable for creating learning communities [25].

From the aforementioned background, it is important to develop a ubiquitous learning system or learning environment using Moodle LMS.

\section{Relevant Literature}

\subsection{The emergence of ubiquitous learning concept}

Basically, "ubiquitous learning" (u-learning) is a continuous evolution of "electronic learning" (e-learning) and "mobile learning" (m-learning) that shifts the learning paradigm from closed to open system. Ubiquitous learning can be explained by the formula "u-learning = e-learning + m-learning", or the integration of $\mathrm{m}$ learning into e-learning environment will shape u-learning [26]. The concept of ulearning, which is strongly influenced by the flow of psychology, humanism, cybernetism, and connectivity, is characterized by the occurrence of a learning 
process through two main approaches, namely: (1) Individual exploration of various learning resources available in an unrestricted environment; and (2) Social interaction with various parties who have direct or indirect relevance to the knowledge learned. Ubiquitous learning is characterized by two dimensions: (1) It is not limited by physical space, plans or schedules but it is pervasive and occurs anywhere, anytime, and (2) As a consequence of the nature that can be distributed and direct access to various sources of information that can reflect on experience in interactions with others, ubiquitous learning is characterized by a transformation of understanding and the ability to explore experiences and information [22].

Yahya, Ahmad \& Jalil [15] explains the difference between u-learning, m-learning, and e-learning from the aspects of concept, permanency, accessibility, immediacy, interactivity, and context-awareness. The differences are presented in Table 1.

Table 1. Differences Between u-Learning, m-Learning, and e-Learning

\begin{tabular}{|c|c|c|c|}
\hline Aspect & u-Learning & m-Learning & e-Learning \\
\hline Concept & $\begin{array}{l}\text { Learn the right thing at the } \\
\text { right place and time in the } \\
\text { right way }\end{array}$ & $\begin{array}{l}\text { Learn at the right place and } \\
\text { time }\end{array}$ & Learn at the right time \\
\hline Permanency & $\begin{array}{l}\text { Learners can never lose their } \\
\text { work. }\end{array}$ & $\begin{array}{l}\text { Learners may lose their work. } \\
\text { Changes in learning devices } \\
\text { or learning in moving will } \\
\text { interrupt } \\
\text { learning activities }\end{array}$ & Learners can lose their work \\
\hline Accessibility & $\begin{array}{l}\text { System access via ubiquitous } \\
\text { computing technologies } \\
\text { System access via ubiquitous } \\
\text { computing technologies }\end{array}$ & $\begin{array}{l}\text { System access via wireless } \\
\text { networks }\end{array}$ & $\begin{array}{l}\text { System access via computer } \\
\text { network }\end{array}$ \\
\hline Immediacy & $\begin{array}{l}\text { Learners get information } \\
\text { immediately }\end{array}$ & $\begin{array}{l}\text { Learners get information } \\
\text { immediately in fixed } \\
\text { environments with specified } \\
\text { mobile learning devices }\end{array}$ & $\begin{array}{l}\text { Learners cannot get } \\
\text { information immediately }\end{array}$ \\
\hline Interactivity & $\begin{array}{l}\text { Learners' interaction with } \\
\text { peers, teachers, and experts } \\
\text { effectively through the } \\
\text { interfaces of u-learning } \\
\text { systems }\end{array}$ & $\begin{array}{l}\text { Learners can interact with } \\
\text { peers, teachers, and experts in } \\
\text { specified learning } \\
\text { environment }\end{array}$ & $\begin{array}{l}\text { Learners' interaction is } \\
\text { limited }\end{array}$ \\
\hline $\begin{array}{l}\text { Context } \\
\text { awareness }\end{array}$ & $\begin{array}{l}\text { The system can understand } \\
\text { the learner's environment via } \\
\text { database and sensing the } \\
\text { learner's location, personal } \\
\text { and environmental situations }\end{array}$ & $\begin{array}{l}\text { The system understands the } \\
\text { learner's situation by } \\
\text { accessing the database }\end{array}$ & $\begin{array}{l}\text { The system cannot sense the } \\
\text { learner's environment }\end{array}$ \\
\hline
\end{tabular}

\subsection{Characteristics of ubiquitous learning environment}

The ubiquitous learning environment is a combination of various settings that support learning by utilizing technology that can encourage authentic, interactive, effective learning experiences and in accordance with student tastes without being bound by time and place [16]. The ubiquitous learning environment is a system that is aware of the context and can know/feel student information and information around students in the real world and can offer personalized services. Therefore, students can 
learn knowledge, skills and solve problems while interacting with the real world through authentic scenarios [27]. The ubiquitous learning environment can create learning activities that are more active and adaptive in the real world. Students can learn at the right time, in the right place, with the right tools and the right content [28].

Chen, Kao, Sheu, \& Chiang [29] and Curtis, Luchini, Bobrowsky, \& Quintana [30] explain the main characteristics of ubiquitous learning, namely: 1) permanency, 2) accessibility, 3) immediacy, 4) interactivity, and 5) situating of instructional activities. Yang, Okamoto, \& Tseng [31] identify eight characteristics of environment for ulearning, namely: 1) mobility, 2) location awareness, 3) interoperability, 4) seamlessness, 5) situation awareness, 6) social awareness, 7) adaptability, and 8) pervasiveness. Meanwhile, Tan \& Min [32] create u-learning as a system that has characteristics of: permanency, accessibility, immediacy, interactivity, situation, calmness, adaptability, seamlessness, and immersion.

Virtanen, Haavisto, Liikanen, \& Kääriäinen [33] identify four criteria of learning environment for ubiquitous learning, namely: 1) context-awareness, 2) interactivity, 3) personalization, dan 4) flexibility.

The context-awareness learning environment can use a web-based Learning Management System, promoting various approaches and functions. Contextawareness supports students to be able to access specific learning resources, content or interactive activities based on their own location, time and activities. Contextawareness supports individual learning as well as content and information management, while instruction and feedback are based on students' own time, location or activities. Context-awareness is an authentic learning environment with the support of personalized digital technology. This allows students to observe or classify real-world objects in learning activities through digital guidance [34]. The context-awareness learning environment enables unlimited learning from one place to another within a given area [28]. The context-awareness is a container of ten contexts, namely personal context, task context, device context, social context, spatial-temporal context, environmental context, user interface, infrastructure, strategic context, and historical-context. The interactivity of learning environment supports various types of interactivity between teacher and students, students and students, and student and peer assistance. A synchronous and asynchronous web-based approach can be used to support interactivity. Personalization and flexibility are intended as opportunities for learning and learning anytime and anywhere, based on students' own schedules, as well as learning objectives or learning needs.

The ubiquitous learning environment allows seamless learning anywhere and anytime. Students are able to study uninterruptedly while moving from one place to another [35]. The ubiquitous learning environment can connect, integrate, and share learning resources in the right place at the right time through interoperable, pervasive and seamless learning environments [36]. The ubiquitous learning environment consists of several components namely learning objects, learning tasks, learning expositions, learning communication and administrative functions [37]. 


\subsection{Development of ubiquitous learning system with moodle LMS}

In education, learning systems using mobile devices offer the potential to realize ubiquitous learning through new ways to access information and think both individually and in network communities, where students collaborate to support the development of new understanding and discussion for new solutions [37]. There are several choices that can be made to build an online learning system. Haryono [38] suggests that there are three different ways to provide an online learning system, namely: 1) developing by self, 2) purchasing an existing system, 3) using open source LMS, and 4) customization.

Moodle is an open source software that supports the implementation of online learning with an integrated paradigm where various learning support features can easily be accommodated in an online learning portal. Moodle online learning systems can be modified as needed. Research has proven that the use of Moodle LMS can enhance learning outside the classroom and has a positive influence on students' thinking and innovation skills [39]-[42]. Moodle LMS has a lot of features that can be used to support the application of ubiquitous learning. Courses on Moodle are areas where a lecturer will add resources and activities to be completed by students [43]. Resources and activities provided on Moodle are presented in Table 2.

Table 2. Resources and Activities in Moodle LMS

\begin{tabular}{|l|l|l|}
\hline \multicolumn{1}{|c|}{ Resource } & \multicolumn{2}{|c|}{ Activities } \\
\hline Book & Assignments & Lesson \\
File & Chat & (LTI) External Tool \\
Folder & Choice & Quiz \\
IMS Content Package & Database & SCORM \\
Label & Feedback & Survey \\
Page & Forum & Wiki \\
URL & Glossary & Workshop \\
\hline
\end{tabular}

Surjono [44] explains the stages to develop an online learning portal using Moodle including: 1) getting a server/webhosting, 2) setting up the Moodle mobile app, 3) changing the portal's identity and theme, 4) creating categories, 5) creating and setting up user status, 6) changing course settings, 7) inputting resources, and 8) creating and managing activities.

\section{Method}

\subsection{Research design}

This study uses the Research and Development for Education (R\&D for Education) method which is a method for producing a product and testing the feasibility of a product for education. The product developed in this study is the ubiquitous learning system in the form of: 1) the u-learning portal built with Moodle LMS, and 2) the ulearning course in the Instructional Media course. 
The stages taken in developing a product adapt the stages of the ADDIE development model proposed by Lee \& Owens [45] including the Analysis, Design, Development, Implementation, and Evaluation stages. This model is chosen because it is simple, complete, and tested. The development model is presented in Figure 1.

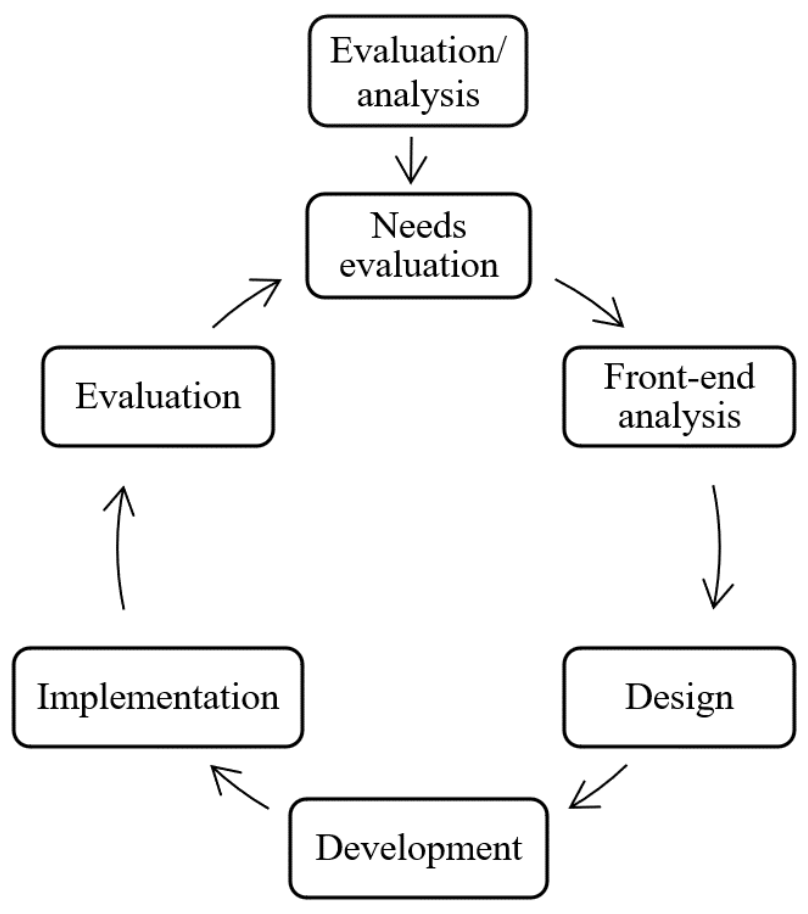

Fig. 1. Development Model of Ubiquitous Learning System (adapted from Lee \& Owens [45])

\subsection{Procedures}

By adapting the Lee \& Owens [45] development model, the u-learning development procedures are described in Table 3. 
Table 3. Stages for u-Learning Development

\begin{tabular}{|c|c|c|}
\hline No. & Stages & Activities \\
\hline 1. & Analysis & $\begin{array}{l}\text { Need evaluation: identifying problems that cause the process and learning } \\
\text { outcomes are not optimal. } \\
\text { Front-end analysis: identifying student characteristics, technology or learning } \\
\text { support facilities provided by campus, the conditions of the learning environment, } \\
\text { as well as the competencies/learning objectives that students must master. } \\
\text { This activity is carried out through interviews, observations, documentary studies, } \\
\text { and questionnaires filled out by student lecturers and students. }\end{array}$ \\
\hline 2. & Design & $\begin{array}{l}\text { Planning a development schedule } \\
\text { Determining hardware and software specification requirements } \\
\text { Determining materials/resources and learning strategies/activities } \\
\text { Designing resources and activities in a program mapping }\end{array}$ \\
\hline 3. & Development & $\begin{array}{l}\text { Creating a u-learning system; this step consists of: } \\
\text { Making a portal: 1) finding server/webhosting, 2) changing the portal identity } \\
\text { (site name, site description), 3) setting up the Moodle mobile app, 4) changing the } \\
\text { theme, 5) creating a category, and } 6 \text { ) creating and setting up user status } \\
\text { Creating courses in instructional media: 1) creating and changing course settings, } \\
\text { 2) inputting resources (Book, File, Folder, IMS Content Package, Labels, Page, } \\
\text { URL), and 3) creating activities (Assignments, Chat, Choice, Database, } \\
\text { Feedback, Forum, Glossary, Lesson, LTI/External Tool, Quiz, SCORM, Survey, } \\
\text { Wiki, Workshop) } \\
\text { Product validation by media experts and material experts } \\
\text { Product revisions }\end{array}$ \\
\hline 4. & Implementation & Product field trial to the students \\
\hline 5. & Evaluation & Final revision and product evaluation \\
\hline
\end{tabular}

\subsection{Product validation \& field trial}

Product validation is carried out by two content/learning materials experts and two instructional media experts by taking into account relevant educational backgrounds and experiences in their fields. This expert validation is important to get input for the improvement of the product being developed and to get assurance that the ubiquitous learning system developed is feasible to be implemented in learning.

Field trial is the application of the system developed to 47 students ( 2 classes) of the Department of Primary School Teacher Education of the Faculty of Education, Universitas Pendidikan Ganesha - Singaraja - Bali - Indonesia. This trial aiming to determine the ability (usability) and product quality, before it is used or applied in real classes. After the application of the product, the students fill out the product evaluation questionnaire followed by data analysis, while product revision is based on the results of the field trials to have the final product. By testing the product, it is expected that the quality of the developed media will be better.

Instrument: The instrument used to validate the ubiquitous learning system is a questionnaire. This questionnaire is filled out by subject matter experts in instructional media, online instructional media experts, and students as users. The questionnaire for material experts is developed by referring to the theory from Walker $\&$ Hess [46], and the questionnaire for online instructional media experts is adapted from a standard /comprehensive rubric for the design of e-learning developed by Debattista [47]. Meanwhile, the questionnaire for students in the field trial is arranged 
based on aspects of the evaluation of the material expert and the media expert by making adjustments (selecting) statements/questions related to the role of students as users of the product being developed. There are two types of questions in this questionnaire namely closed-ended and open-ended question types. Closed-ended questions are arranged using a scale of 5 (Likert scale), while open-ended questions are used to solicit opinions or suggestions from experts and students for the product being developed. Questionnaire grids for material experts and media experts are presented in Table 4 and Table 5.

Table 4. Instruments for Learning Material Evaluation

\begin{tabular}{|c|l|l|}
\hline Aspect to Assess & \multicolumn{2}{|c|}{ Indicators } \\
\hline Material Aspects & $\begin{array}{l}\text { Appropriate material with the } \\
\text { competencies to be achieved } \\
\text { Truth of the concept } \\
\text { Updated material }\end{array}$ & $\begin{array}{l}\text { Order of material deliveries } \\
\text { Appropriate examples given }\end{array}$ \\
\hline Learning Aspects & $\begin{array}{l}\text { Learning Objectives } \\
\text { Motivation } \\
\text { Summary }\end{array}$ & $\begin{array}{l}\text { Clarity of learning indicators } \\
\text { Providing training } \\
\text { Appropriate images, videos provided to } \\
\text { clarify the material }\end{array}$ \\
\hline Language Aspects & $\begin{array}{l}\text { Appropriate language in accordance } \\
\text { with students' level of thinking } \\
\text { Simple language } \\
\text { Appropriate terms }\end{array}$ & $\begin{array}{l}\text { Appropriate grammar and spelling } \\
\text { Ability to encourage student curiosity }\end{array}$ \\
\hline
\end{tabular}

Table 5. Instrument for Online Instructional Media Evaluation

\begin{tabular}{|c|c|c|}
\hline Main Standards & \multicolumn{2}{|c|}{ Specific Standards } \\
\hline Course opening & $\begin{array}{l}\text { Accessibility } \\
\text { Role } \\
\text { Description } \\
\text { Behaviour }\end{array}$ & $\begin{array}{l}\text { Integrity } \\
\text { Technical competences } \\
\text { Ownership }\end{array}$ \\
\hline $\begin{array}{l}\text { Instructional resources for } \\
\text { teaching and learning }\end{array}$ & $\begin{array}{l}\text { Provision } \\
\text { Application } \\
\text { Entitlement }\end{array}$ & $\begin{array}{l}\text { Variety } \\
\text { Openness } \\
\text { Academic integrity }\end{array}$ \\
\hline Interaction and community & \begin{tabular}{|l} 
Fostering \\
Management
\end{tabular} & Peer learning \\
\hline Learner support & $\begin{array}{l}\text { Instructional support } \\
\text { Academic support }\end{array}$ & $\begin{array}{l}\text { Technical support } \\
\text { Administrative support }\end{array}$ \\
\hline Technology design & $\begin{array}{l}\text { Support } \\
\text { Centricity } \\
\text { Openness } \\
\text { Authentication }\end{array}$ & \begin{tabular}{|l} 
Access \\
Interface \\
Investment \\
Management \\
\end{tabular} \\
\hline Course closing & $\begin{array}{l}\text { Assessment } \\
\text { Resolution }\end{array}$ & Archiving \\
\hline Assessment of learning & $\begin{array}{l}\text { Goals and objectives } \\
\text { Strategies } \\
\text { Grading }\end{array}$ & $\begin{array}{l}\text { Feedback } \\
\text { Management }\end{array}$ \\
\hline Instructional design cycle & $\begin{array}{l}\text { Academic review } \\
\text { Technical review }\end{array}$ & Administrative review \\
\hline
\end{tabular}


Data Analysis: The data obtained from the validation of the ubiquitous learning system are classified into 2, namely qualitative data and quantitative data. Qualitative data include criticisms and suggestions put forward by material experts and instructional media experts. These data are collected and abstracted to improve the developed ubiquitous learning system. Meanwhile, quantitative data include scores on each of the instrument items that has been filled by material experts and instructional media experts. Descriptive statistical analysis techniques are used to provide the value/quality of the developed ubiquitous learning system. The scores obtained are then summed and averaged, then converted to value by using the table criterionreferenced test 5 scale adapted from Sukarjo [48] as presented in Table 6.

Table 6. Score Conversion to Value on a 5 Scale

\begin{tabular}{|l|l|l|}
\hline \multicolumn{1}{|c|}{ Score/Category } & \multicolumn{2}{c|}{ Score } \\
\cline { 2 - 3 } & \multicolumn{1}{c|}{ Pattern } & \multicolumn{1}{c|}{ Calculation } \\
\hline Excellent & $\mathrm{X}>\bar{X}_{i}+1,80 \mathrm{Sdi}$ & $\mathrm{X}>4,21$ \\
\hline Very good & $\bar{X}_{i}+0,60 \mathrm{Sdi}<\mathrm{X} \leq \bar{X}_{i}+1,80 \mathrm{Sdi}$ & $3,40<\mathrm{X} \leq 4,21$ \\
\hline Good & $\bar{X}_{i}-0,60 \mathrm{Sdi}<\mathrm{X} \leq \bar{X}_{i}+0,60 \mathrm{Sdi}$ & $2,60<\mathrm{X} \leq 3,40$ \\
\hline Average & $\bar{X}_{i}-1,80 \mathrm{Sdi}<\mathrm{X} \leq \bar{X}_{i}-0,60 \mathrm{Sdi}$ & $1,79<\mathrm{X} \leq 2,60$ \\
\hline Poor & $\mathrm{X} \leq \bar{X}_{i}-1,80 \mathrm{Sdi}$ & $\mathrm{X} \leq 1,79$ \\
\hline
\end{tabular}

Where:

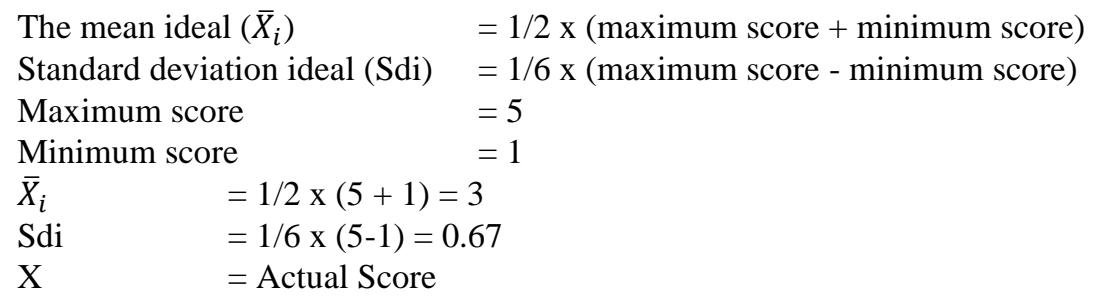

To locate the average score (mean score) of an assessment of the product that has been developed, the following formula is used:

$$
\bar{X}_{i}=\frac{\sum X}{n}
$$

Where:

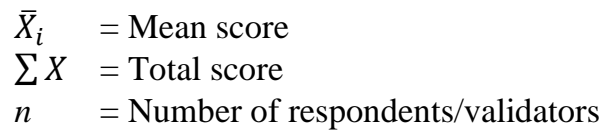

In this study, the feasibility of a minimum set value of "Very good", as the result of assessment by the subject matter expert and instructional media expert. If the results of the final assessment (overall) at least got an "Very good" by experts, the ubiquitous learning system of the development results can be considered appropriate to be applied in learning processes. 


\section{$4 \quad$ Result}

\subsection{Result of the evaluation/analysis phase}

Analysis was carried out to identify problems that cause optimal learning goals was not achieved optimally, student characteristics, competencies that students must master, as well as technology or learning support facilities provided in campus, and the conditions of the learning environment. The results of this analysis included qualitative data obtained through interviews, observations, documentation studies and questionnaires filled out by lecturers and students of the Department of Primary School Teacher Education of the Faculty of Education, Universitas Pendidikan Ganesha.

Some of the causes of the low learning outcomes of Instructional Media course are: 1) Students claim to have difficulty in understanding Instructional Media course material, 2) They are not happy to learn using only textbooks, modules, or textbooks, and 3) In partial Instructional Media courses large students/classes have never been taught by using e-learning.

Students of the Department of Primary School Teacher Education have been the ability to operate mobile devices, have smartphones running on Android and iOS operating system, prefer accessing information through their smartphones than using a laptop or PC, are happy to be able to explore independently the various learning resources available in a broad environment, through social interaction with various parties who have direct or indirect relevance to the material being studied.

Meanwhile, the Instructional Media course has characteristics such as having a wide enough range of material both theoretical material and practical empirical. Specifically, the competencies that students must master after taking this course are having knowledge, skills and attitudes in the fields of design, development, utilization, evaluation and study of media in learning. This Instructional media course with 3 credits ( 1 credit equivalent to 50 minutes), meaning that the study time provided in class was less compared to the broad material demanding more time. Therefore, learning can be done anywhere, anytime, and in any way (ubiquitous learning) to be the right solution for completion of this course.

In terms of environmental support and infrastructure, the Department of Primary School Teacher Education of the Faculty of Education, Universitas Pendidikan Ganesha has 1 computer laboratory unit with 36 PCs, 16 mobile devices (iPad), WiFi for internet connections, and almost all lecturers and students have mobile devices (smartphone) and have the ability to use computers and adequate internet access which can be a driving motor for the application of ubiquitous learning.

\subsection{Design of ubiquitous learning system for instructional media course}

Once the analysis was done, designing the ubiquitous learning design in the instructional media course was the next step to take. To make the u-learning course, it is necessary to prepare learning material in digital format. Learning material can be in 
the form of documents (doc, pdf, xls, txt), presentations (ppt), images (jpg, gif, png), videos (mpg, wmv), sounds (mp3, au, wav), and animations (swf, gif). These files need to be organized in such a way as a program mapping so that they are easy to find and use when developing $\mathrm{u}$-learning system. Program mapping is a table that contains learning material for one semester; where in each element, there is a link that is connected to the complete material [49]. The program mapping of ubiquitous learning for Instructional Media course is presented in Table 7.

Table 7. Program Mapping of Ubiquitous Learning for the Instructional Media Course

\begin{tabular}{|c|c|c|c|c|}
\hline \multirow{2}{*}{ Topic } & \multirow{2}{*}{$\begin{array}{c}\text { Type of Learning } \\
\text { Material }\end{array}$} & \multicolumn{2}{|c|}{ Features of Moodle LMS } & \multirow{2}{*}{$\begin{array}{c}\text { Application of } \\
\text { u-Learning Principle }\end{array}$} \\
\hline & & Resource & Activities & \\
\hline $\begin{array}{l}\text { Basic concept of } \\
\text { instructional media }\end{array}$ & $\begin{array}{l}\text { Document (pdf) } \\
\text { Presentation (ppt) }\end{array}$ & $\begin{array}{l}\text { Page } \\
\text { File } \\
\text { URL }\end{array}$ & $\begin{array}{l}\text { Forum } \\
\text { Assignments (online } \\
\text { text) } \\
\text { Feedback }\end{array}$ & $\begin{array}{l}\text { Permanency } \\
\text { Mobility } \\
\text { Accessibility }\end{array}$ \\
\hline $\begin{array}{l}\text { Classification of } \\
\text { instructional media }\end{array}$ & \begin{tabular}{|l|} 
Document (doc, pdf) \\
Presentation (ppt) \\
Picture (jpg, png)
\end{tabular} & $\begin{array}{l}\text { Book } \\
\text { File } \\
\text { URL }\end{array}$ & $\begin{array}{l}\text { Assignments (file } \\
\text { submission) } \\
\text { Chatting } \\
\text { Feedback } \\
\end{array}$ & $\begin{array}{l}\text { Immediacy } \\
\text { Interactivity } \\
\text { Flexibility }\end{array}$ \\
\hline $\begin{array}{l}\text { Characteristics of } \\
\text { instructional media }\end{array}$ & $\begin{array}{l}\text { Document (pdf) } \\
\text { Presentation (ppt) } \\
\text { Animation (swf) } \\
\text { Multimedia (exe) }\end{array}$ & $\begin{array}{l}\text { File } \\
\text { URL }\end{array}$ & $\begin{array}{l}\text { BigBlueButtonBN } \\
\text { (web conference) } \\
\text { Messages }\end{array}$ & $\begin{array}{l}\text { Context-Awareness: } \\
\text { task context } \\
\text { social context } \\
\text { environmental context } \\
\text { Seamlessness } \\
\text { Pervasiveness } \\
\end{array}$ \\
\hline $\begin{array}{l}\text { Management of } \\
\text { instructional media }\end{array}$ & $\begin{array}{l}\text { Document (pdf) } \\
\text { Presentation (ppt) }\end{array}$ & $\begin{array}{l}\text { File } \\
\text { URL }\end{array}$ & $\begin{array}{l}\text { Lesson } \\
\text { Feedback }\end{array}$ & $\begin{array}{l}\text { Context-Awareness: } \\
\text { historical context } \\
\text { Immersion }\end{array}$ \\
\hline $\begin{array}{l}\text { Development (need } \\
\text { evaluation, design, } \\
\text { production, and } \\
\text { evaluation) of } \\
\text { instructional media }\end{array}$ & \begin{tabular}{|l|} 
Document (doc, pdf, \\
xls) \\
Presentation (ppt) \\
Picture (jpg, gif, png)
\end{tabular} & $\begin{array}{l}\text { Label } \\
\text { Page }\end{array}$ & $\begin{array}{l}\text { Workshop } \\
\text { Assignments (file } \\
\text { submission) }\end{array}$ & $\begin{array}{l}\text { Interactivity } \\
\text { Flexibility } \\
\text { Context-Awareness: } \\
\text { personal context } \\
\text { task context } \\
\text { device context }\end{array}$ \\
\hline
\end{tabular}

\subsection{Final product}

The final product of this development research is the u-learning portal called $\mathrm{u}$ Learning Class. U-learning can be accessed on https://u-learningclass.site. In this portal, there are eight course categories, and Instructional Media course as objects of this research are in semester I categories. The homepage display of the u-learning portal is presented in Figure 2.

The Instructional Media course has various components that enable the creation of learning that meets the principles and according to the characteristics of u-learning itself, namely: 1) permanency, 2) accessibility, 3) immediacy, 4) interactivity, and 5) context awareness by utilizing various resources and activities contained in Moodle. One learning segment is organized by utilizing the BigBlueButtonBN feature. This feature is used to create online classrooms in real-time (web conferencing) in distance learning, in which lecturers and students can be anywhere. The features include: 1) 
slideshow presentation, 2) live or streaming video, 3) VoIP, 4) meeting recording, 5) whiteboard, 6) text chat, 7) polls and surveys, and 8) screen sharing/desktop sharing/application sharing. Screenshots of this activity can be seen in Figure 3.

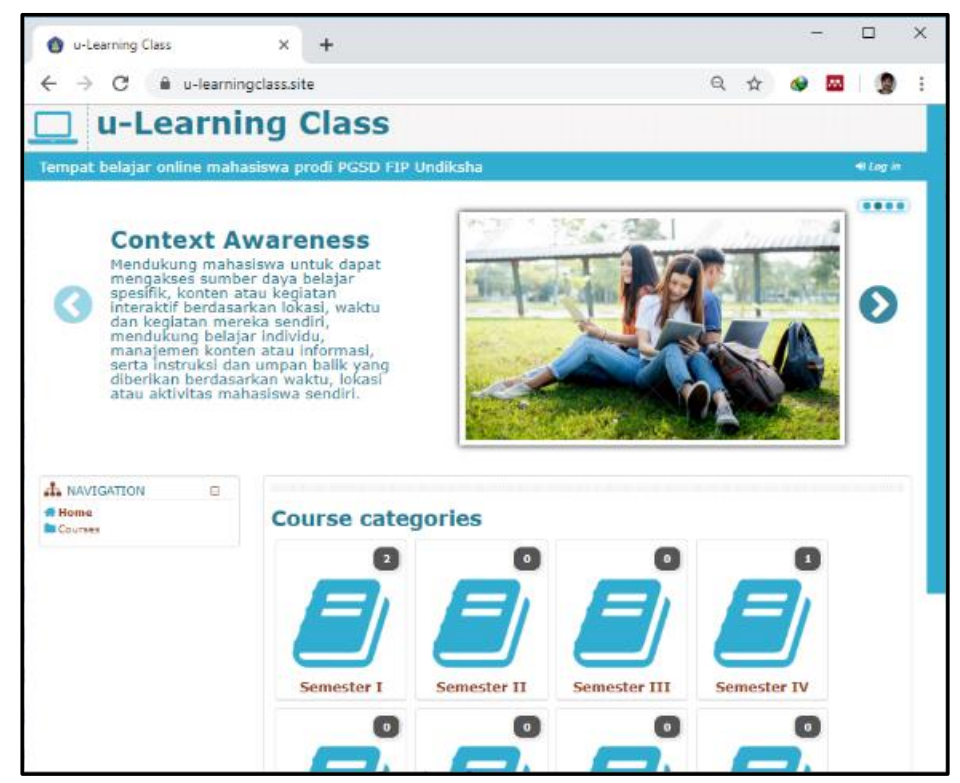

Fig. 2. Homepage of u-Learning Portal

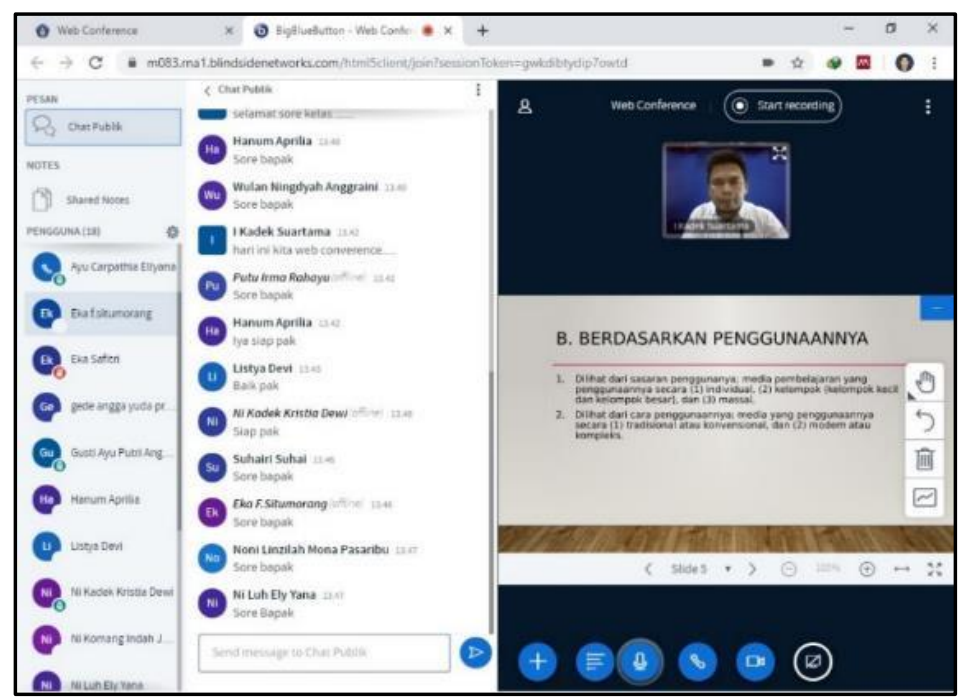

Fig. 3. The Usage of BigBlueButtonBN (Video Conference) Features to Apply the Principles of Permanency, Accessibility, Immediacy, and Interactivity 
Furthermore, the application of the ubiquitous learning principles especially for the context awareness, is to provide assignments for students to conduct observations in the field/school to identify the types of instructional media in an authentic learning environment through guidance that is carried out digitally based on their own location, time and activities. Independent student exploration of various learning resources available in an unlimited environment and social interaction with various parties who have direct or indirect relevance to the knowledge learned are the applications of the context awareness principles (task context, social context, and environmental context). To achieve this goal, the Assignment, Chat and Feedback features were used. Screenshot of this activity can be seen in Figure 4.

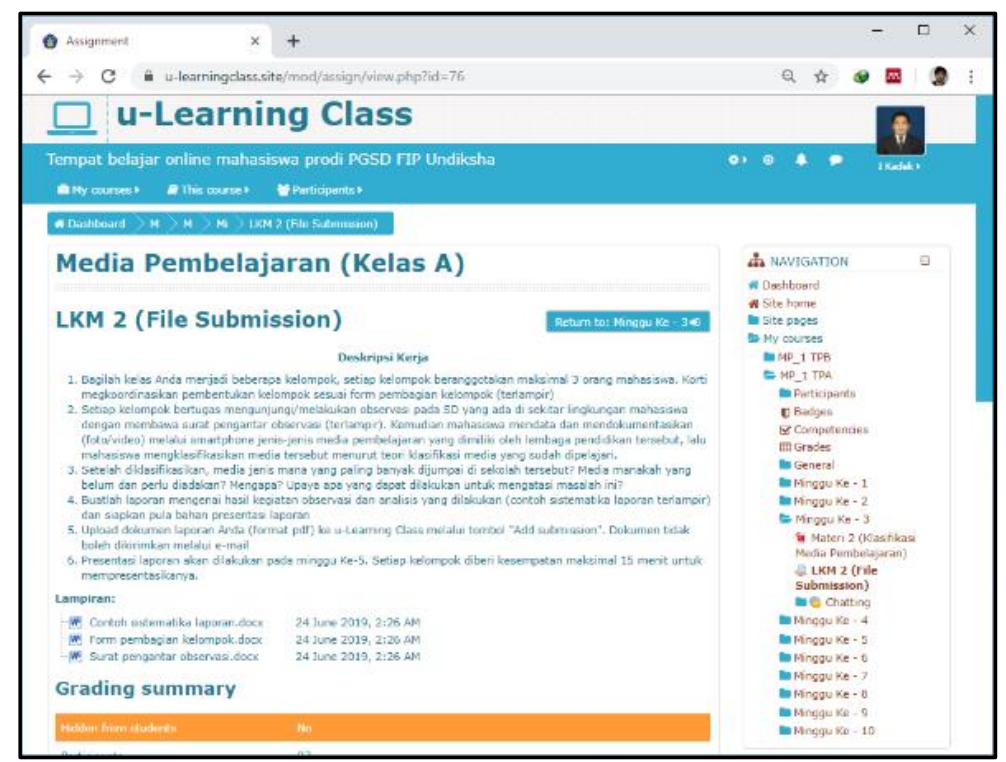

Fig. 4. The Usage of Assignment Feature to Apply the Principles of Context-Awareness (Task Context, Social Context, and Environmental Context)

In other segments, learning activities were designed to support the historical context principles (related to the history or past experience of students) which is also an element of the context awareness principles. The Lesson feature was used to implement the historical context principles. The Lesson feature allows the lecturer to convey content and/or practice activities in an interesting, flexible, and adaptive way (adjusting to student achievement). Lecturers can create a linear set of content pages or learning activities that offer various paths or options for students. In this case, the lecturer can know or ensure students' understanding by giving various statements/questions. Meanwhile, students are given true-false statements (true-false). Student answer choices can be used to determine the next activity; students who answer correctly can advance to the next page/problem, while students who answer incorrectly are brought back to the previous page/enrichment material or diverted to the path or discussion page. Screenshot of this activity can be seen in Figure 5. 


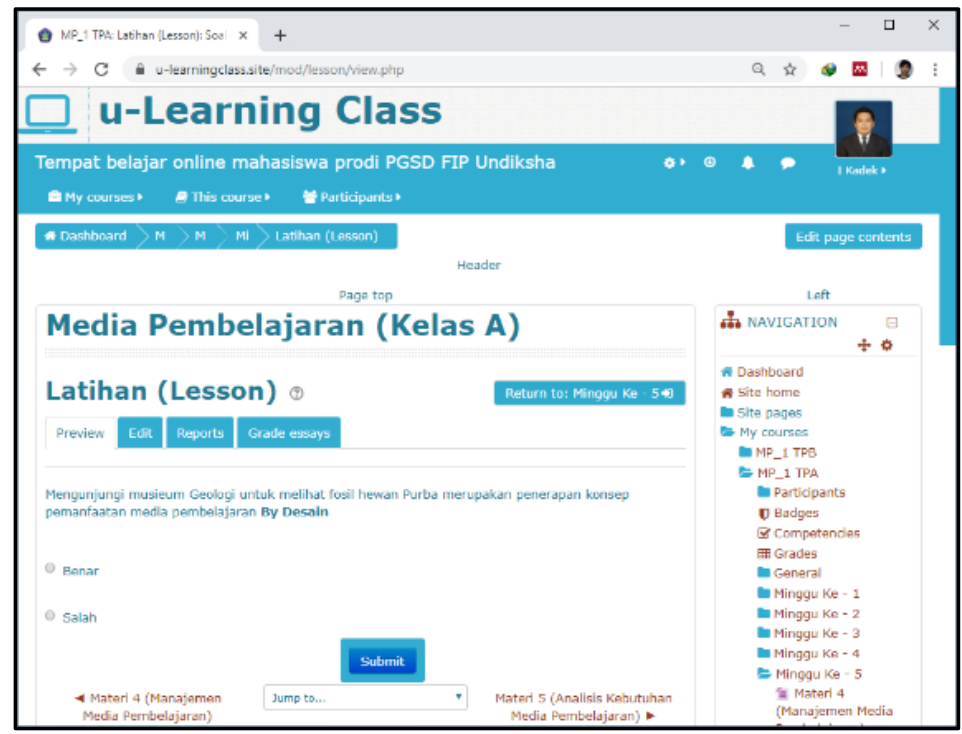

Fig. 5. The Usage of Lesson Feature to Apply the Principles of ContextAwareness (Historical Context)

\subsection{Result of product validation \& field trial}

After an internal test to check whether the product runs smoothly, the evaluation stages were then conducted including: (1) Validation by material experts and media experts, and (2) Field trials to 47 students (2 classes).

The results of the evaluation from two material/content experts on product quality are presented in Table 8.

Table 8. Results of Content Expert Validation on Ubiquitous Learning Systems in the Instructional Media courses

\begin{tabular}{|l|c|l|}
\hline \multicolumn{1}{|c|}{ Evaluation Aspects } & Average Score & \multicolumn{1}{c|}{ Category } \\
\hline Material Aspect & 4.80 & Excellent \\
\hline Learning Aspect & 4.67 & Excellent \\
\hline Language Aspect & 4.80 & Excellent \\
\hline Total Average Score & 4.76 & Excellent \\
\hline
\end{tabular}

From Table 8 above, it is known that the mean score of the overall evaluation of the material/content aspect of learning reaches 4.76. Referring to the table of conversion of quantitative data to qualitative data in 5 scale, is categorized into "Excellent", which means that the learning material developed is feasible to be applied in learning processes.

The suggestions for revision/improvement from expert learning materials included: 1) Adding enrichment materials from learning resources available on the internet, and 2) Adding learning materials related to mastering higher competencies. 
The results of the evaluation from two media experts on product quality are presented in Table 9.

Table 9. Results of Media Expert Validation on the Ubiquitous Learning System in The Instructional Media Course

\begin{tabular}{|l|c|l|}
\hline \multicolumn{1}{|c|}{ Evaluation Aspects } & Average Score & \multicolumn{1}{c|}{ Category } \\
\hline Course opening & 4.43 & Excellent \\
\hline Instructional resources for teaching and learning & 4.50 & Excellent \\
\hline Interaction and community & 4.33 & Excellent \\
\hline Learner support & 4.50 & Excellent \\
\hline Technology design & 4.50 & Excellent \\
\hline Course closing & 4.67 & Excellent \\
\hline Evaluation of learning & 4.60 & Excellent \\
\hline Instructional design cycle & 4.33 & Excellent \\
\hline Total Average Score & 4.48 & Excellent \\
\hline
\end{tabular}

From Table 9 above, it is known that the average score of the whole aspects of instructional media scores reaches 4.48. Referring to the table of conversion of quantitative data to qualitative data in 5 scale, is categorized into "Excellent", which means that the media developed is feasible to be applied in learning processes. The suggestions for revision/improvement from learning media experts included: 1) Adding instructions for each learning activity, 2) Structuring learning objects to be more easily understood by students, and 3) Adding more instructional media in accordance with the type of knowledge or content.

Furthermore, the evaluation results of the 47 students in field trials on product quality are presented in Table 10 .

Table 10. Result of Student Evaluation on Ubiquitous Learning System for Instructional Media Course

\begin{tabular}{|l|c|l|}
\hline \multicolumn{1}{|c|}{ Evaluation Aspects } & Average Score & \multicolumn{1}{c|}{ Category } \\
\hline Material Aspect & 4.62 & Excellent \\
\hline Learning Aspect & 4.62 & Excellent \\
\hline Language Aspect & 4.64 & Excellent \\
\hline Course opening & 4.75 & Excellent \\
\hline Instructional resources for teaching and learning & 4.59 & Excellent \\
\hline Interaction and community & 4.64 & Excellent \\
\hline Learner support & 4.53 & Excellent \\
\hline Technology design & 4.59 & Excellent \\
\hline Course closing & 4.68 & Excellent \\
\hline Evaluation of learning & 4.71 & Excellent \\
\hline Instructional design cycle & 4.57 & Excellent \\
\hline Total Average Score & 4.63 & Excellent \\
\hline
\end{tabular}

From Table 10, it is known that the average score of the overall evaluation of the ubiquitous learning system aspects in the Instructional Media course reaches 4.63. Referring to the table of conversion of quantitative data to qualitative data in 5 scale, 
is categorized into "Excellent", which means that the system developed is feasible to be applied in learning processes.

In general, responses from students during the field trial about this product included: 1) Students felt happy because the material and learning activities presented online made learning activities more flexible, 2) Students were bolder and more free in expressing their opinions in online discussion forums, usually students are shy and afraid to express their arguments in class/face-to-face meetings, 3) Collection of assignments, reports, Student Worksheets was online and did not require printout making the cost of study/lecture more efficient, and 4) Using the Moodle mobile application made it easier to operate and makes access to the u-learning system faster.

\section{Discussion}

The process of developing u-learning for the Instructional Media course has been completed through five stages, namely: analysis, design, development, implementation, and evaluation. This process can run smoothly, quickly, and more organized because it is based on the planning that has been made beforehand and the readiness of the materials needed based on the results of the analysis that has been done.

From the evaluation of material experts shows that it falls into "Excellent" category; the evaluation of the media experts shows that it falls into "Excellent" category, and the field trial to the students shows that it falls into "Excellent" category. Therefore, it can be concluded that the u-learning system has met the eligibility criteria to be used in learning processes.

There are some reasons for this product to be considered worth it to be used in learning prosesses. The u-learning system for the Instructional Media course has combined delivery ways, teaching models and learning styles, introducing a wide selection of learning media or learning resources and various interaction formats between lecturers and students and between students and students by utilizing various features of mobile application (Moodle LMS). The selection of the Moodle LMS application in u-learning settings has been able to provide several advantages, namely: 1) It provides different formats of learning activities such as weekly format, topic format, and social format, 2) It is flexible in determining activities for example: community, journals, quizzes, selected questions, surveys, tasks, chats, 3) All class members in forums, journals, quizzes, and tasks can be viewed on a single page (and can be downloaded as a spreadsheet file), and 4) It is able to display various user activities [43].

The ubiquitous learning system for instructional media course was emphasized to the maximum student activities to seek and find the materials (put the student as a subject of study). In the learning process, students do not only act as a receiver in passive way, they will construct their knowledge on their own way. The entire activities of the student were directed to seek and find the answers by themselves from something that is questionable, so as to foster self-confidence (self-belief), to develop intellectual abilities and mastery of higher competence as part of the mental 
process [1]. Thus, the ubiquitous learning system can minimize the chances of negative events happen in the learning process by using mobile devices.

The ubiquitous learning system provides various learning methods such as individual learning, group work, fieldwork, and project-based learning. Furthermore, it provides various instructional media or resources (documents, presentations, animations, and multimedia) which are tailored to student learning preferences. This will be able to provide creativity modeling to students, encourage students to be more active and be able to find ways of learning that are suitable for themselves. By using methods that are appropriate to the material and characteristics of students will be able to create a conducive learning atmosphere and improve student learning achievement [14].

The application of the context-awareness principle was conducted by asking students to do assignments in the field which are facilitated with an interactive guidance mechanism (digital guidance based on their own location, time and activities) to help students recognize and differentiate learning objects in the real world. Interactive guides help students collect and organize what they observe and learn in the real world. Wu, Hwang, \& Tsai [50] found that context-awareness ubiquitous learning can significantly improve learning achievement in several cognitive processes in Bloom's taxonomy such as "analyzing" and "evaluating". In addition, context-aware ubiquitous learning with an interactive guide approach has benefited students in improving higher-level thinking competencies. Learning activities in the field (out-of-class learning) will help students to achieve some valuable learning outcomes, can help students to increase intellectual growth, can expose students to the potential of the job market, and know opportunities for success in the future [51].

The use of message, chat and forum features is intended to create interaction between lecturers and students, as well as students and students. Mediated social interaction with online computers is important in education because it can provide benefits such as flexibility, efficiency in terms of cost and time. Araújo [52] show that social and collaborative interactions in the ubiquitous learning environment can improve student performance, suggesting that interactive features enhance the interaction of cooperative learning and enhance the teaching/learning processes.

This u-learning product has another advantage, i.e. the direct feedback given by the lecturer to the work done by students. This feedback shows positive or negative reinforcement from lecturers. Feedback, building on assessment, allows students to gauge their progress, consider alternate learning strategies, and project their own continued learning needs [53]. This diverse evaluation method and the students access rights to their grades will be able to spur students to continue to study hard so that they can show excellent performance in class.

The responses from students to the u-learning course developed indicated that this product has the advantage of having a good level of interactivity that is able to make students interested and active in the learning process. Student interest in the media of u-learning is one indicator of the student learning motivations and is an excellent indicator for improving the learning process and outcomes [54]. The user interface is interesting since this $\mathrm{u}$-learning product provide the home page, ease of navigation, 
and the combination of text, colors, and a very harmonious background. In addition to an interesting user interface, in each material, this media is equipped with examples of images, animations, videos, and multimedia so that students or users can better understand it.

The students considered that this u-learning product is easy to access. They only need to type the URL: https://u-learningclass.site in the address bar of the browser to take benefits of this u-learning portal. Furthermore, the use of Moodle mobile application makes it easier for students to use it and access to e-learning systems faster. The u-learning material can be accessed more quickly, anytime, and anywhere, besides that material that can be enriched with various learning resources including multimedia that can be quickly updated by lecturers. Students can also conduct monitoring, communication, and cooperation. On the other hand, students can of course download learning material, do assignments and quizzes, and participate in chat and discussion forums.

Based on the explanation above, the principles of ubiquitous learning such as permanency, accessibility, immediacy, interactivity, and context awareness can be applied to the learning system developed.

\section{Conclusion}

In recent years, information technology has been integrated into educational practices that have produced a series of trends including electronic learning (elearning), mobile learning (m-learning) and ubiquitous learning (u-learning). Ulearning practices are still being developed, along with problems such as the difficulty of students to focus on learning objectives and quite ineffective learning tools/strategies. This study has successfully developed the ubiquitous learning environment by optimizing various ubiquitous learning principles through Moodle LMS. This system can create learning activities that can be done anywhere, anytime, and in any way based on students' needs and characteristics.

The development of the ubiquitous learning system has been carried out through the stages including analysis, design, evaluation, implementation, and evaluation. The principles of ubiquitous learning have been able to be implemented using various features (resources and activities) contained in Moodle LMS. The usage of File, URL, Chat, Forum, BigBlueButtonBN (Video Conference) features can realize the principles of permanency, accessibility, immediacy, and interactivity. Using the Assignment feature (online text \& file submission) can realize the principle of context-awareness in terms of task context, social context, and environmental context, while the Lesson feature is used to apply the principle of historical context.

Evaluation of several aspects of learning materials such as content/material aspects, learning aspects, language aspects show the results in the "Excellent" category. Furthermore, the evaluation of several aspects of learning media such as course opening, interaction and community, instructional resources for teaching and learning, learner support, technology design, course closing, evaluation of learning, instructional design cycle show results in the "Excellent" category. Therefore, this 
means that the ubiquitous learning system in this Instructional Media course is feasible to be applied in learning processes.

\section{$7 \quad$ Acknowledgement}

This study was supported by BPPDN scholarship from the Ministry of Research, Technology, and Higher Education of the Republic of Indonesia.

\section{$8 \quad$ References}

[1] BADA, \& Olusegun, S. (2015). Constructivism Learning Theory: A Paradigm for Teaching and Learning. Journal of Research \& Method in Education, 5(6), 66-70.

[2] Potkonjak, V., Gardner, M., Callaghan, V., Mattila, P., Guetl, C., Petrović, V. M., \& Jovanović, K. (2016). Virtual laboratories for education in science, technology, and engineering: A review. Computers and Education, 95, 309-327. https://doi.org/10.1016/j. compedu.2016.02.002

[3] Huang, Y. M., Chiu, P. S., Liu, T. C., \& Chen, T. S. (2011). The design and implementation of a meaningful learning-based evaluation method for ubiquitous learning. Computers and Education, 57(4), 2291-2302. https://doi.org/10.1016/j.compedu.2011.05.0 $\underline{23}$

[4] Vlădoiu, M. (2012). Towards Instructional Design of Ubiquitous Learning Environments. International Journal of Computer\&OrganizationTrends-IJCOT, 2, 108-112. Retrieved from http://www.ijcotjournal.org/archive/ijcot-v2i4p305

[5] Elfeky, A. I. M., \& Yakoub Masadeh, T. S. (2016). The Effect of Mobile Learning on Students' Achievement and Conversational Skills. International Journal of Higher Education, 5(3), 20-31. https://doi.org/10.5430/ijhe.v5n3p20

[6] Furió, D., Juan, M. C., Seguí, I., \& Vivó, R. (2015). Mobile learning vs. traditional classroom lessons: A comparative study. Journal of Computer Assisted Learning, 31(3), 189-201. https://doi.org/10.1111/jcal.12071

[7] García-Peñalvo, F. J., \& Conde, M. (2015). The impact of a mobile personal learning environment in different educational contexts. Universal Access in the Information Society, 14(3), 375-387. https://doi.org/10.1007/s10209-014-0366-Z

[8] Filali Marzouki, O., Khalidi Idrissi, M., \& Bennani, S. (2017). Effects of Social Constructivist Mobile Learning Environments on Knowledge Acquisition: A MetaAnalysis. International Journal of Interactive Mobile Technologies (IJIM), 11(1), 18. https://doi.org/10.3991/ijim.v11i1.5982

[9] Odukoya, J. A., Adekeye, O., \& Okunlola, S. (2017). Assessing the Effectiveness of Mobile Learning Devices in Tertiary Institutions: The Experience of Undergraduates in a Nigerian Private University. International Journal of Interactive Mobile Technologies (IJIM), 11(4), 160. https://doi.org/10.3991/ijim.v11i4.6828

[10] Smith, R. (2008). Motivational Factors in E-learning. George Washington University.

[11] Mortaza Mokhtari Nazarlou. (2013). Research on Negative Effect on E-Learning. International Journal of Mobile Network Communications \& Telematics, 3(2), 11-16. https://doi.org/10.5121/ijmnct.2013.3202

[12] Chu, H. C. (2014). Potential negative effects of mobile learning on students' learning achievement and cognitive load-a format assessment perspective. Educational Technology and Society, 17(1), 332-344. https://doi.org/10.2307/jeductechsoci.17.1.332 
[13] Hao, S., Dennen, V. P., \& Mei, L. (2017). Influential factors for mobile learning acceptance among Chinese users. Educational Technology Research and Development, 65(1), 101-123. https://doi.org/10.1007/s11423-016-9465-2

[14] Munawaroh. (2017). The Influence of Teaching Methods and Learning Environment to the Student's Learning Achievement of Craft and Entrepreneurship Subjects at Vocational High School. International Journal of Environmental \& Science Education, 12(4), 665678.

[15] Yahya, S., Ahmad, E. A., \& Jalil, K. A. (2010). The definition and characteristics of ubiquitous learning: A discussion. International Journal of Education and Development Using Information and Communication Technology, 6(1), 1-12. https://doi.org/10.1098/rstb.1971.0019

[16] Virtanen, M. A. (2018). The development of ubiquitous 360 learning environment and its effects on students' satisfaction and histotechnological knowledge. Graduate School University of Oulu.

[17] Kinshuk, \& Graf, S. (2012). Ubiquitous Learning. In Encyclopedia of the Sciences of Learning (pp. 3361-3363). Boston, MA: Springer US. https://doi.org/10.1007/978-1-44191428-6_224

[18] Cope, B., \& Kalantzis, M. (2008). Ubiquitous Learning: An agenda for educational transformation. In Proceedings of the 6th International Conference on Networked Learning (Vol. ISBN No: 9, pp. 576-582). https://doi.org/ISBN\%20978-1-86220-206-1

[19] Zixue Cheng, Shengguo Sun, Kansen, M., Tongjun Huang, \& Aiguo He. (2005). A Personalized Ubiquitous Education Support Environment by Comparing Learning Instructional. In 19th International Conference on Advanced Information Networking and Applications (AINA'05) Volume 1 (AINA papers) (Vol. 2, pp. 567-573). Taiwan: IEEE. https://doi.org/10.1109/AINA.2005.46

[20] Haruo, N., Koyoharu, P.H., Yasufumi, K. \& Shiho, M. (2003). Designing Ubiquitous and Universal Learning Situations: Integrating Textbooks and Mobile Devices. In 19th Annual Conference on Distance Teaching and Learning. Madison Wisconsin, USA.

[21] Chang, C. Y., \& Sheu, J. P. (2002). Design and implementation of ad hoc classroom and eSchoolbag systems for ubiquitous learning. Proceedings - IEEE International Workshop on Wireless and Mobile Technologies in Education, WMTE 2002. https://doi.org/10.1109/ WMTE.2002.1039215

[22] Goh, T. T. (2010). Multiplatform e-learning systems and technologies: Mobile devices for ubiquitous ICT-based education. Information Science Reference-Imprint of: IGI Publishing Hershey, PA. USA. https://doi.org/10.4018/978-1-60566-703-4

[23] Lau, R. K. W. (2006). Designing a ubiquitous learning workspace for conducting creative thinking exercise in tertiary design education. In Fourth IEEE International Workshop on Wireless, Mobile and Ubiquitous Technology in Education, WMUTE 2006 (pp. 36-38). https://doi.org/10.1109/WMTE.2006.261342

[24] Brandl, K. (2005). Are You Ready to "MOODLE"? Language Learning \& Technology, 9(2), 16-23. https://doi.org/10.5449/idslu-001091490.75

[25] Forment, M., Guerrero, J. C. (2008). MOODLBILE: Extending Moodle to the Mobile On/Offline Scenario. In IADIS International Conference on Mobile Learning.

[26] Casey, D. (2005). u-Learning = e-Learning + m-Learning. In G. Richards (Ed.). In ELearn: World Conference on E-Learning in Corporate, Government, Healthcare, and Higher Education (Vol. 2005, pp. 2864-2871). AACE. Retrieved from https://www.learntechlib.org/primary/p/21634/

[27] Chiu, P.; Kuo, Y.; Huang, Y.; Chen, T. (2008). A Meaningful Learning based u-Learning Evaluation Model. In Eighth IEEE International Conference on Advanced Learning Technologies. https://doi.org/10.1109/icalt.2008.100

[28] Hwang, G.-J., Tsai, C.-C., \& Yang, S. J. H. (2008). Criteria, Strategies and Research Issues of Context-Aware Ubiquitous Learning. Educational Technology \& Society, 11(2), 81-91. 
[29] Chen, Y. S., Kao, T. C., Sheu, J. P., \& Chiang, C. Y. (2002). A mobile scaffolding-aidbased bird-watching learning system. In Proceedings - IEEE International Workshop on Wireless and Mobile Technologies in Education, WMTE 2002 (pp. 15-22). https://doi.org/ 10.1109/WMTE.2002.1039216

[30] Michael Curtis, Kathleen Luchini, William Bobrowsky, Chris Quintana, E. S. (2002). Handheld Use in K-12: A Descriptive Account. In IEEE International Workshop on Wireless and Mobile Technologies in Education (WMTE'02) (pp. 23-30). https://doi.org/ $10.1136 / \mathrm{bmj} .2 .5413 .881-\mathrm{c}$

[31] Yang, S.J., Okamoto, T., \& Tseng, S. (2008). Context-Aware and Ubiquitous Learning (Guest Editorial). Educational Technology \& Society, 11(2), 1-2.

[32] Tan-Hsu Tan, Min-Sheng Lin, Y.-L. C. and T.-Y. L. (2012). Educational Affordances of a Ubiquitous Learning Environment in a Natural Science Course. Educational Technology \& Society, 15(2), 206-219. https://doi.org/10.1109/ICALT.2009.32

[33] Virtanen, M. A., Haavisto, E., Liikanen, E., \& Kääriäinen, M. (2018). Ubiquitous learning environments in higher education: A scoping literature review. Education and Information Technologies, 23(2), 985-998. https://doi.org/10.1007/s10639-017-9646-6

[34] Hwang, G.-J., Chu, H.-C., Shih, J.-L., Huang, S.-H., \& Tsai, C.-C. (2010). A DecisionTree-Oriented Guidance Mechanism for Conducting Nature Science Observation Activities in a Context-Aware Ubiquitous Learning Environment. Journal of Educational Technology \& Society, 13(2), 53-64. https://doi.org/10.2307/jeductechsoci.13.2.53

[35] Chiu, P., Kuo, Y., Huang, Y., \& Chen, T. (2008). The ubiquitous learning evaluation method based on meaningful learning. In The nternational conference oncomputers in education. Taipei, Taiwan.

[36] Yang, S. J. H. (2006). Context aware ubiquitous learning environments for peer-to-peer collaborative learning. Educational Technology and Society, 9(1), 188-201. https://doi.org/10.1186/1477-7517-7-24

[37] Dochev, D., \& Hristov, I. (2006). Mobile learning applications ubiquitous characteristics and technological solutions. Cybernetics and Information Technologies, 6(3), 63-74.

[38] Haryono. (2011). Pengenalan E-learning. Jurnal Dharma Pendidikan. Retrieved from http://dharmapendidikan.blogspot.com/2011/03/pengenalan-e-learning.html

[39] Georgouli, K., Skalkidis, I., \& Guerreiro, P. (2008). A Framework for Adopting LMS to Introduce e-Learning in a Traditional Course, 11(2), 227-240. https://doi.org/10.2307 /jeductechsoci.11.2.227

[40] Govender, I. (2009). The learning context: Influence on learning to program. Computers and Education, 53(4), 1218-1230. https://doi.org/10.1016/j.compedu.2009.06.005

[41] Henderson, J. G. (2011). Learning Through a Disciplined Curriculum Study Approach. Scholar-Practitioner Quarterly, 4(4), 312-315.

[42] Chootongchai, S., \& Songkram, N. (2018). Design and development of SECI and moodle online learning systems to enhance thinking and innovation skills for higher education learners. International Journal of Emerging Technologies in Learning, 13(3), 154-172. https://doi.org/10.3991/ijet.v13i03.7991

[43] Suartama, I. K., Setyosari, P., Sulthoni, \& Ulfa, S. (2019). Development of an Instructional Design Model for Mobile Blended Learning in Higher Education. International Journal of Emerging Technologies in Learning (IJET), 14(16), 4-22. https://doi.org/10.3991/ijet.v14 i16.10633

[44] Surjono, H. D. (2010). Pengembangan Course E-Learning Berbasis Moodle. Yogyakarta: UNY Press.

[45] Lee, W. W., \& Owens, D. L. (2004). Multimedia Based Instructional Design: Computer Based Training Web Based Training Distance Broadcast Training, Performance Based Solutions (2nd ed.). San Fransisco: Pfeiffer.

[46] Walker, D. F., \& Hess, R. D. (1984). Instructional software: Principles and perspectives for design and use. Belmont: Wadsworth Publishing Company. 
[47] Debattista, M. (2018). A comprehensive rubric for instructional design in e-learning. International Journal of Information and Learning Technology, 35(2), 93-104. https://doi. org/10.1108/IJILT-09-2017-0092

[48] Sukardjo. (2010). Evaluasi Pembelajaran. Buku Pegangan Kuliah. PPs Universitas Negeri Yogyakarta.

[49] Suartama, I. K., \& Tastra, I. D. K. (2014). E-Learning Berbasis Moodle. Yogyakarta: Graha Ilmu.

[50] Wu, P.-H., Hwang, G.-J., \& Tsai, W.-H. (2013). An expert system-based context-aware ubiquitous learning approach for conducting science learning activities. Educational Technology \& Society, 16(4), 217-230.

[51] Kam, H. J., \& Katerattanakul, P. (2019). Enhancing student learning in cybersecurity education using an out-of-class learning approach. Journal of Information Technology Education: Innovations in Practice, 18, 29-47. https://doi.org/10.28945/4200

[52] Araújo, R. D., Brant-Ribeiro, T., Mendonça, I. E. S., Mendes, M. M., Dorça, F. A., \& Cattelan, R. G. (2017). Social and collaborative interactions for educational content enrichment in ULEs. Educational Technology and Society, 20(3), 133-144.

[53] Bonnel, W. (2008). Improving Feedback to Students in Online Courses. Nursing Education Perspectives, 29(5), 290-294.

[54] Demir, K., \& Akpinar, E. (2018). The effect of mobile learning applications on students' academic achievement and attitudes toward mobile learning, 6(2), 48-59. https://doi.org/10.17220/mojet.2018.02.004

\section{Authors}

I Kadek Suartama is a lecturer in the Department of Educational Technology, Universitas Pendidikan Ganesha, Singaraja, Indonesia. His research interests are e-learning, multimedia learning, and mobile learning.

Punaji Setyosari is a professor in the post Graduate program of the Department of Education and Technology, Universitas Negeri Malang, Malang, Indonesia. His research interests include research methodologies, evaluation and assessment, instructional media, problem-based learning, and collaborative learning.

Sulthoni is a lecturer in the Department of Educational Technology, Universitas Negeri Malang, Malang, Indonesia. His research interests include instructional media and learning strategies.

Saida Ulfa is a lecturer in the Department of Educational Technology, Universitas Negeri Malang, Malang, Indonesia. Her research interests include mobile learning, instructional media, and learning engineering.

Article submitted 2019-09-26. Resubmitted 2020-05-16. Final acceptance 2020-05-16. Final version published as submitted by the authors. 